\title{
Structure Prediction of Delta Aminolevulinic Acid Dehydratase (ALAD); An Enzyme that is Very Sensitive to the Toxic Effects of Lead
}

\section{Zahra Batool* and Asma Haque}

Department of Bioinformatics and Biotechnology, Quaid-i-Azam University Islamabad, Pakistan

\begin{abstract}
The ALAD (Aminolevulinic Acid Dehydratase) gene polymorphism is linked with the accumulation of lead in the bone, blood and the other internal organs and it may predispose for many critical symptoms in the lead exposed persons. The aim of this study is to determine the primary, secondary and tertiary structure of lead. This enzyme is susceptible towards the toxic effect of lead. Primary structure prediction was done by Protparam tool, Compute PI/MW tool, Proscale tool. Secondary structure prediction was done by Self -optimize prediction method (SOPMA) tool, Porter tool. Tertiary structure prediction was done by protein structure prediction server. Domain was determined by Simple Modular Architecture Research (SMART) tool.
\end{abstract}

Keywords: ALAD; Toxic effects; Lead

\section{Introduction}

Lead is an environmental toxic metal, which is capable of causing many chronic diseases. Important sources of lead include pipes, lead containing paints, gasoline containing lead, and the different kinds of canned foods. Lead is distributed in the bone, blood and the soft tissues after absorption. There is about $99 \%$ lead bounds to the red blood cells, and $1 \%$ is present in the plasma, and it is available for the exchange in other tissues. There is 30 days half-life of lead in persons having a normal renal function but it becomes longer in those who have the renal insufficiency [1].

Oxidative stress is a very major effect of lead [2]. The mechanism of lead-induced oxidative stress involves an imbalance between generation and removal of ROS (Reactive Oxygen Species) in tissues and cellular components causing damage to membranes, DNA and proteins [3]. Oxidative stress causes oxidation of membrane lipoproteins and oxidation of DNA leading to tissue damage.

The ALAD (aminolevulinic acid dehydratase) gene polymorphism is linked with the accumulation of lead in the bone, blood and the other internal organs and it may predispose for many critical symptoms in the lead exposed persons. There are a lot of different reports here that give us information about the neurotoxic effects of the lead on the workers exposed to lead [4].

\section{Methodology}

The sequence of Delta aminolevulinic acid dehydratase (ALAD) was taken from National center for Biotechnology Information (NCBI). Accession number of sequence that was studied in this project is AAC60582.1. The structure of this sequence was predicted by several tools. Bioinformatics tools were used for determination of primary, secondary and tertiary structure of amino levulinic acid dehydratase (ALAD). Primary structure prediction was done by Protparam tool, Compute PI/MW tool, Proscale tool. Secondary structure prediction was done Self-optimize prediction method (SOPMA) tool, Porter tool. Tertiary structure prediction was done by protein structure prediction server. Domain was determined by Simple Modular Architecture Research (SMART) tool.

\section{Results}

According to proparam tool its Amino acid sequence is 330,
Molecular weight is 36324.9 Dalton and Theoretical PI value is 6.32, formula is $\mathrm{C}_{1619} \mathrm{H}_{2549} \mathrm{~N}_{4470465} \mathrm{~S}_{19}$.

Total numbers of atoms are 5099, Extinction coefficient is 34880, Estimated half-life is 30 hours, Instability index is 46.43 , Aliphatic index is 89.33 . Grand average of hydropathicity is -0.043 , Total number of negatively charged residues (Asp + Glu) are 38 and Total number of positively charged residues (Arg + Lys) are 35. Its amino acid composition is given below:

\section{Amino acid composition}

The amino acid composition was given in Table 1.

\section{Atomic composition}

The atomic composition was explained in Table 2 and Figure 1.

\section{According to porter tool}

MQPQSVLHSGYFHPLLRAWQTATTTLNASNLIYPIFVTDVPDDIQPITSLPGVARYGVKR

C C C C C C C H H H C C C H H H H H H H H C C C C C C H H HEEEEEEEECCCCCEEECCCCCCCEEECHHН

\begin{tabular}{|l|c|c|}
\hline \multicolumn{2}{|c|}{ Atomic composition } \\
\hline Carbon & C & 1619 \\
\hline Hydrogen & H & 2549 \\
\hline Nitrogen & N & 447 \\
\hline Oxygen & O & 465 \\
\hline Sulfur & S & 19 \\
\hline
\end{tabular}

Table 1: Amino acid composition.

*Corresponding author: Zahra Batool, Department of Bioinformatics and Biotechnology, Quaid-i-Azam University Islamabad, 45320, Pakistan, Tel: +920519064 0000; E-mail: batoolzara23@gmail.com

Received September 28, 2015; Accepted October 17, 2015; Published October 26, 2015

Citation: Batool Z, Haque A (2015) Structure Prediction of Delta Aminolevulinic Acid Dehydratase (ALAD); An Enzyme that is Very Sensitive to the Toxic Effects of Lead. J Biom Biostat 6: 259. doi:10.4172/2155-6180.1000259

Copyright: $\odot 2015$ Batool Z, et al. This is an open-access article distributed under the terms of the Creative Commons Attribution License, which permits unrestricted use, distribution, and reproduction in any medium, provided the original author and source are credited. 
Citation: Batool Z, Haque A (2015) Structure Prediction of Delta Aminolevulinic Acid Dehydratase (ALAD); An Enzyme that is Very Sensitive to the Toxic Effects of Lead. J Biom Biostat 6: 259. doi:10.4172/2155-6180.1000259

Page 2 of 3

\begin{tabular}{|c|c|c|}
\hline \multicolumn{3}{|c|}{ Amino acid composition } \\
\hline Ala (A) & 39 & $11.8 \%$ \\
\hline Arg (R) & 23 & $7.0 \%$ \\
\hline Asn (N) & 5 & $1.5 \%$ \\
\hline Asp (D) & 18 & $5.5 \%$ \\
\hline Cys (C) & 8 & $2.4 \%$ \\
\hline Gln (Q) & 10 & $3.0 \%$ \\
\hline Glu (E) & 20 & $6.1 \%$ \\
\hline Gly (G) & 23 & $7.0 \%$ \\
\hline His (H) & 9 & $2.7 \%$ \\
\hline Ile (I) & 12 & $3.6 \%$ \\
\hline Leu (L) & 35 & $10.6 \%$ \\
\hline Lys (K) & 12 & $3.6 \%$ \\
\hline Met (M) & 11 & $3.3 \%$ \\
\hline Phe (F) & 12 & $3.6 \%$ \\
\hline
\end{tabular}

Source: According to Compute $\mathrm{PI} / \mathrm{Mw}$ its Theoretical $\mathrm{pl} / \mathrm{Mw}$ is $6.32 / 36324.91$ Dalton

Table 2: Tables Shows the Atomic composition.

\begin{tabular}{|c|c|c|c|}
\hline Name & Begin & End & E-Value \\
\hline ALAD 2 & 327 & 9.53 & e-181 \\
\hline
\end{tabular}

Table 3: Confidently predicted domains, repeats, motifs and features.

\begin{tabular}{|l|l|l|l|l|}
\hline Name & Begin & End & E-Value & Reason \\
\hline YccV-LIKE & 53 & 151 & $1.53 \mathrm{E}+05$ & Threshold \\
\hline DWA & 53 & 139 & $3.9 \mathrm{e}+03$ & Threshold \\
\hline MR-MLE & 61 & 181 & $1.59 \mathrm{e}+05$ & Threshold \\
\hline PHD & 109 & 163 & $1.78 .+03$ & Threshold \\
\hline PTI & 110 & 133 & $3.47+02$ & Threshold \\
\hline CGCG & 116 & 196 & $3.61 \mathrm{e}+04$ & Threshold \\
\hline IB & 117 & 176 & $1.44 \mathrm{e}+03$ & Threshold \\
\hline ChtBD1 & 121 & 144 & $1.26 \mathrm{e}+03$ & Threshold \\
\hline CM-2 & 142 & 204 & $1.41 \mathrm{e}+05$ & Threshold \\
\hline HTH-ARAC & 144 & 222 & $2.26 \mathrm{e}+03$ & Threshold \\
\hline SAP & 170 & 201 & $1.65 \mathrm{e}+05$ & Threshold \\
\hline HMG & 252 & 309 & $2.62 \mathrm{e}+03$ & Threshold \\
\hline
\end{tabular}

Table 4: These features and domains are not shown in the diagram, either because their scores are less significant than the required threshold, or because they overlap some other source of annotation.

LEEMLRPLVEEGLRCVLIFGVPSRVPKDERGSAADSEESPAIEAIHLLRKTFPNLLVACD

HHHHHHНHНHCCCCEEEEEEECCCCCCCCCCHHHHCCCCHНHНHНHНHНHНCCCCEEEEE

VCLCPYTSHGHCGLLSENGAFRAEESRQRLAEVALAYAKAGCQVVAPSDMMDGRVEAIKE

ECССССССССССССЕСССССЕССНHНННННННННННННHНСCCEЕEЕССССССНHНHНHН

A L M A H G L G N R V S V M S Y S A K F A S C F Y G P FRD A A KS SPAFGDRRCY QLPPGARGLALRA V D R H H H H C C C C C C C E E E E E E E E E C C C C C H H H H H H НСССССССССССССЕССССНННННННННН

DVREGADMLMVKPGMPYLDIVREVKDKHPDLPLTVYHVSGEFAMLWHGAQAGAFDLKAAV

H H H C C C C E E E E E C C H H H H H H H H H H H H HCCCCCEЕEЕЕСНHНHНHНHНHННСССССННННН

LEAMTAFRRAGADIIITYYTPQLLQWLKEE

НHНHНHНHНHCCCEEEECCHHНHНHНCCCC

(seq. similarity up to $98.5 \%$ ).

\section{According to SOPMA}

Alpha helix (Hh) : 141 is $42.73 \%, 3_{10}$ helix $(\mathrm{Gg}): 0$ is $0.00 \%$, Pi helix (Ii) : 0 is $0.00 \%$, Beta bridge (Bb) : 0 is $0.00 \%$, Extended strand (Ee) : 52 is $15.76 \%$, Beta turn (Tt) : 30 is $9.09 \%$, Bend region (Ss) : 0 is $0.00 \%$, Random coil (Cc) : 107 is $32.42 \%$, Ambigous states (?) : 0 is $0.00 \%$, Other states: 0 is $0.00 \%$ (Figure 2) (Tables 3 and 4).

\section{Discussion and Conclusion}

Lead is recognized as a toxic metal that is the cause of many dangerous diseases in humans. It is considered as the most clinically important heavy metal because it induces a broad range of physiological, biochemical, and behavioral dysfunctions. One of the major mechanisms by which lead exerts its toxic effect is through biochemical processes that include lead's ability to inhibit or mimic the actions of calcium and to interact with proteins. Many investigators have demonstrated that lead intoxication induced cellular damage mediated by the formation of reactive oxygen species [5].

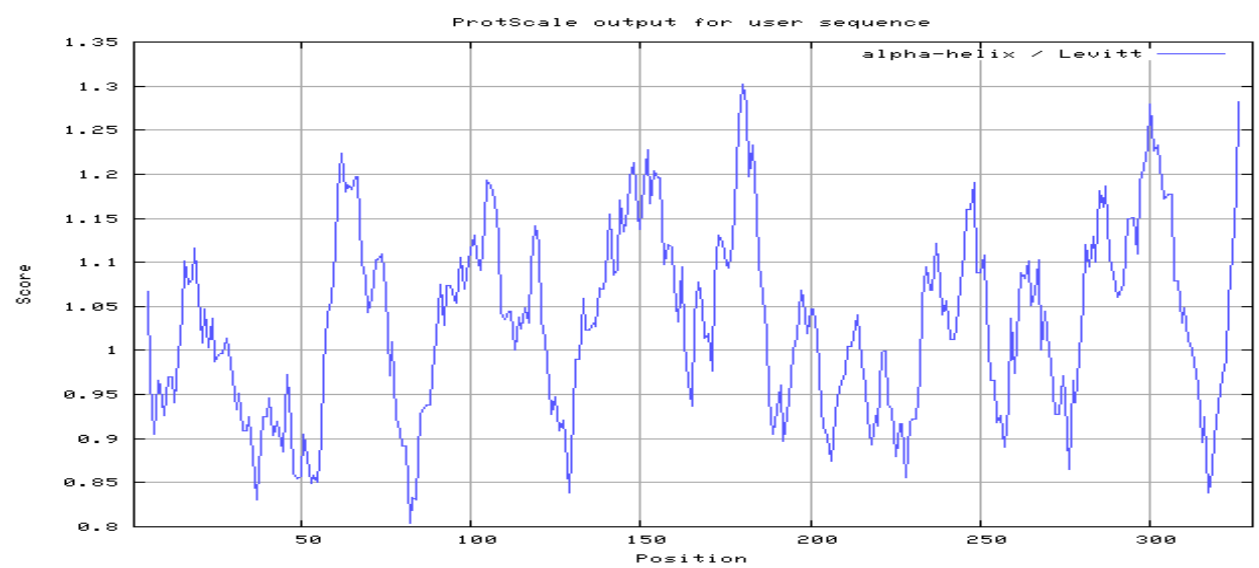

Figure 1: Below represents the Graphical form of ProtsScale. 
Citation: Batool Z, Haque A (2015) Structure Prediction of Delta Aminolevulinic Acid Dehydratase (ALAD); An Enzyme that is Very Sensitive to the Toxic Effects of Lead. J Biom Biostat 6: 259. doi:10.4172/2155-6180.1000259

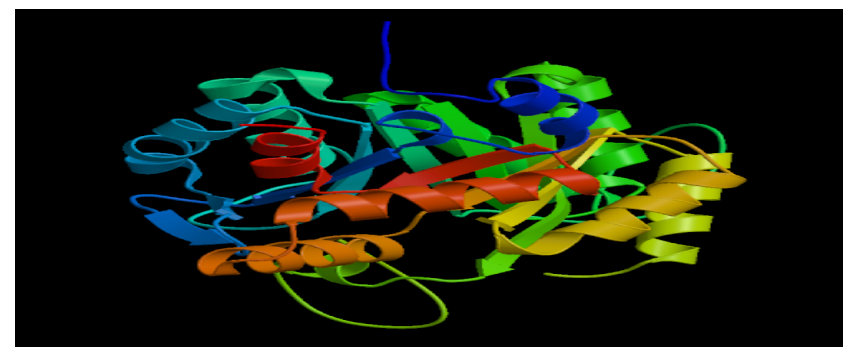

Domain of ALAD

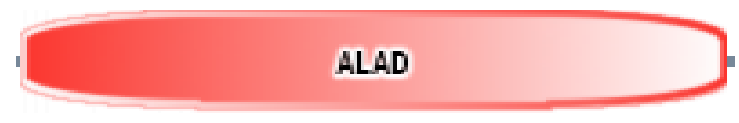

Figure 2: Shows the Tertiary structure of ALAD.

According to primary structure prediction tools the molecular weight of Aminolevulinic acid dehydratase (ALAD) is 36324.9 Dalton, Theoretical Isoelectric Point value is 6.32 and number of amino acids are 330 which is supported by previous studies. It was proposed by Farant and Wigfield [6] Aminolevulinic acid dehydratase is highly sensitive to the toxic effects of lead.

Protein structure prediction server was developed by Chen [7] for determination of tertiary structure of proteins. In this study tertiary structure of aminolevulinic acid dehydratase is determined by protein structure prediction server that used PSI-BLAST and IMPALA for template selection, T-Coffee for target-template alignment, MODELLER for model building and CHIME for visualization of protein model.

SMART (simple modular architecture research tool) tool was developed by Schultz [8] that allows rapid identification of signaling domains of proteins and annotation of signaling domain sequences of proteins. The tool contains several unique aspects, including automatic seed alignment generation, automatic detection of repeated motifs or domains, and a protocol for combining domain predictions from homologous subfamilies. In this study domain of Aminolevulinc acid dehydratase is determined by the use of SMART tool. This tool predicts one domain of Aminolevulinic acid dehydratase [9].

\section{Acknowledgments}

These studies are supported by GC University Faisalabad and partially by University of Agriculture Faisalabad. Ethical committee is thanked for permission to carry out this work.

\section{References}

1. Hryhorczuk DO, Rabinowitz MB, HessI SM, Hoffman D, Hogan MM, et al. (1985) Elimination kinetics of blood lead in workers with chronic lead intoxication. Am $\mathrm{J}$ Ind Med 8: 33-42.

2. Gürer H, Ozgünes H, Neal R, Spitz DR, Erçal N (1998) Antioxidant effects of $\mathrm{N}$-acetylcysteine and succimer in red blood cells from lead-exposed rats. Toxicology 128: 181-189.

3. Halliwell B, Gutteridge JMC (1989) Protection against oxidants in biologyogical systems: the superoxide theory of oxygen toxicity in Free Radical in Biology and Medicine. Clarendon Press Oxford, UK.

4. Kelada SN, Shelton E, Kaufmann RB, Khoury MJ (2001) Delta-aminolevulinic acid dehydratase genotype and lead toxicity: a HuGE review. Am J Epidemiol 154: $1-13$

5. Hermes-lima M, Valle VGR, Vercesi AE, Bechara EJH (1991) Damage to rat liver mitochondria promoted by d-aminolevulinic Acid-generated reactive oxygen species: connections with acute Intermittent porphria and lead poisoning. Biochim Biophys Acta 1: 57-63.

6. Farant JP, Wigfield DC (1982) Biomonitoring lead exposure with deltaaminolevulinate dehydratase (ALA-D) activity ratios. Int Arch Occup Environ Health 51: 15-24.

7. Chen CC, Hwang JK, Yang JM (2006) (PS)2: protein structure prediction server. Nucleic Acids Res 34: W152-157.

8. Schultz J, Milpetz F, Bork P, Ponting CP (1998) SMART, a simple modula architecture research tool: identification of signaling domains. Proc Natl Acad Sci U S A 95: 5857-5864.

9. Muntner P, Menke A, DeSalvo KB, Rabito FA, Batuman V (2005) Continued decline in blood lead levels among adults in the United States: the National Health and Nutrition Examination Surveys. Arch Intern Med 165: 2155-2161. 